\title{
Business models innovation in investment banks: a resilience perspective
}

\section{Boumediene Ramdani ${ }^{1}$ (D) Ahmed Binsaif $^{2} \cdot$ Elias Boukrami $^{3}$ (D) Cherif Guermat ${ }^{4}$ (D)}

Published online: 17 June 2020

(C) The Author(s) 2020

\begin{abstract}
Firms frequently change their business models in order to respond to internal and external challenges. This study aims to explore how investments banks adjust their business models in response to internal and external challenges. Based on a qualitative data from ten major investment banks operating in the largest financial market in the Middle East, we show that investment banks can achieve resilience by adjusting their business models through continuous activity changes in response to internal and external challenges. Specifically, investment banks adjust their business models through deploying alternative combinations of activities from a broad repertoire of activities. Within the same bank, divisions that respond to external challenges tend to sustain their performance, whereas resilient divisions that respond to both internal and external challenges tend to bounce back or achieve substantial increase in performance levels. This study contributes to the literature by proposing resilience as an alternative approach to business model innovation and by providing insight into how firms adjust their business models by altering specific activities in response to both internal and external challenges.
\end{abstract}

Keywords Business model innovation - Investmentbanks · Financial services · Resilience Saudi Arabia $\cdot$ Middle East

Firms frequently change their business models (BMs) in order to respond to internal and external challenges. While some firms need to respond to internal challenges such as organisational capabilities (Teece, 2018), and learning processes (Futterer, Schmidt,

Boumediene Ramdani

B.Ramdani@qu.edu.qa

1 Centre for Entrepreneurship, College of Business \& Economics, Qatar University, Doha, Qatar

2 Riyadh, Saudi Arabia

3 Regent's University London, London, UK

4 University of the West of England, Bristol, UK 
\& Heidenreich, 2018), other firms need to address external challenges such as changing demands of stakeholders (Amit \& Zott, 2015), new technology (Cozzolino, Verona, \& Rothaermel, 2018), and deregulation (Casadesus-Masanell \& Ricart, 2010). Business Model Innovation (BMI) has been suggested as a way to respond to these challenges by adjusting BMs, and as a new source of innovation that goes beyond product and process innovation (Osiyevskyy \& Dewald, 2015). Although there is no commonly recognised definition of a $\mathrm{BM}$, scholars tend to agree that a $\mathrm{BM}$ is about the value proposition the enterprise delivers to its customers, how it creates that value, and how it captures a portion of it (Wirtz, Pistoia, Ullrich, \& Göttel, 2016; Massa, Tucci, \& Afuah, 2017; Foss \& Saebi, 2017). Moreover, researchers are increasingly becoming interested in how BM evolves over time (Saebi, Lien, \& Foss, 2017).

There is an ongoing debate regarding what constitutes a BMI. Some scholars claim that BMI constitutes varying degrees of innovation. As Khanagha et al. (2014: p. 324) put it "activities can range from incremental changes in individual components of business models, extension of the existing business model, introduction of parallel business models, right through to disruption of the business model, which may potentially entail replacing the existing model with a fundamentally different one". Researchers advocating this inclusive definition highlight that BMI could be new to the firm as well as new to the industry. Studies show that BMI may affect only a single component (e.g. Schneider \& Spieth, 2013), "one or more" components (e.g. Sorescu, Frambach, Singh, Rangaswamy, \& Bridges, 2011), "two or more" components (e.g. Lindgardt, Reeves, Stalk, \& Deimler, 2009), or the entire BM components and the links between the components (e.g. Velamuri, Bansemir, Neyer, \& Möslein, 2013). However, other scholars stress that BMI has to be new to the industry (e.g. Aspara, Hietanen, \& Tikkanen, 2010). Innovation here is typically disruptive where a completely new BM is introduced. In differentiating the types of BMI, Foss and Saebi (2017) use two dimensions of BMI, namely the degree of novelty (new to a firm vs. new to an industry), and scope of innovation (modular vs. architectural change). As a result, they suggest four types of BMI: evolutionary (finetuning process), adaptive (changes in the overall BM that are new to a firm), focussed (changes within one area of the BM), and complex (change the entire BM).

The BMI literature suggests that firms can adjust their BMs through adaptation, which is "the process by which management actively aligns the firm's business model to a changing environment" (Saebi et al., 2017, p. 569). Some studies focus on how firms adapt their BMs suggesting several approaches namely trial-and-error (Morris, Schindehutte, \& Allen, 2005), learning (Teece, 2010), fine-tuning process (Demil \& Lecocq, 2010), and continuous adjustments (Landau, Karna, \& Sailer, 2016). Other studies focus on the conditions facilitating BMI. Firms are more likely to adapt their BMs under conditions of perceived threat than under conditions of perceived opportunities (Saebi et al., 2017). Despite the numerous studies on the drivers (e.g. Saebi et al., 2017), processes (e.g. Landau et al., 2016), and consequences (e.g. McNamara, Peck, \& Sasson, 2013) of BM adaptation, there is still limited knowledge of how firms adjust their BMs.

Another less explored avenue for adjusting BMs is resilience, which is the ability "to respond more quickly, recover faster or develop more unusual ways of doing business under duress than others" (Linnenluecke, 2017: p. 4). Dewald and Bowen (2010) suggest that "resilience depends on a simultaneous internal and external evaluation of the situation" (p. 212). This line of research stops short of disclosing how firms adjust their BMs in response to internal and external challenges. To fill this gap, our study 
aims to explore how investments banks can achieve resilience by adjusting their BMs in response to both internal and external challenges.

We choose to study investment banks for at least two reasons. First, Crotty (2009) argues that investment banking is a complex and risky business, and investment banks face continuous shift in market and regulatory environments. For instance, five of the largest independent investment banks in the US lost their independence in 2008: Bear Stearns and Lehman Brothers failed, Merrill Lynch was taken over by Bank of America, and Goldman Sachs and Morgan Stanley became bank holding companies to qualify for bailout money (Crotty, 2009). One of the main reasons for their failure has been attributed to the ambiguity and complexity of their BMs. This could be due to running multiple divisions (i.e. Asset Management, Brokerage, Investment Banking, and Custody Services) independently with 'Chinese Wall arrangements' (Lipton \& Mazur, 1975) to avoid conflicts of interest. Second, investment banks throughout the world have made significant changes to their BMs after the 2008 financial crisis as they were forced by regulators to entirely abandon their old BMs by maintaining lower levels of leverage and accepting lower risk and lower returns (Teece, 2010).

Political and economic instabilities are real challenges for businesses in general and investment banks in particular throughout the Middle East. Saudi Arabia, as well as the Gulf region, has been hit by at least three major crises in the past three decades. The first crisis was the invasion of Kuwait by Iraq in August 1990, and the ensuing Gulf war that threatened not only the economies of the Gulf states but also their very existence (Finlan, 2003). The second major crisis was the 2006 IPO crisis in Saudi Arabia. This crisis was caused by an oversubscription to company shares on the Saudi stock market (Jeambey, 2007). From a peak on 25 February 2006, the Saudi stock market index fell by about 65\% (Lerner, Leamon, \& Dew, 2017). The crisis was felt across the entire Gulf economies. The third crisis was the 2008 global financial crisis, which caused the Saudi stock market to fall even further than it had in 2006 (Lerner et al., 2017). In addition, the Middle East region is wellknown for its political instability; ranging from the Iraq-Iran war, the Arab Spring, to the current wars in Yemen, Syria and Libya.

Since the 1980s, the financial sector in Saudi Arabia has been given a priority as part of the Saudi government diversification policy away from the dependence on oil revenues (Samargandi, Fidrmuc, \& Ghosh, 2014). As a result, the government has built financial markets, an efficient banking system, and a competitive insurance sector. Recently, the government launched the National Transformation Program (Saudi Vision 2030). Evidence suggests that although Saudi Arabia still depends on the oil sector, investment in Saudi stock market boosts Saudi economic growth (Jawadi \& Ftiti, 2019). The shift in the Saudi policy makers towards a more sustainable economy and away from oil dependence makes investment banks an ideal context to study how firms adjust their BMs in response to internal and external challenges.

\section{Theoretical background}

\section{Business model resilience}

An emerging body of research in BMI advocates that firms respond to internal and external challenges through resilience. According to Lengnick-Hall and Beck (2005), 
resilience is an organisational capacity to adjust routines in order to overcome challenges. BM resilience has emerged as one of the key themes in a recent review of resilience in business and management research (Linnenluecke, 2017). Research in this area posits that firms are able to respond to challenges through continuously adjusting, adapting and reinventing their BMs. However, "the boundaries of organizational resilience have been ill defined and wide ranging" (Dewald \& Bowen, 2010: p. 199). This field has included studies that range from continuous adjustment (Hamel \& Valikangas, 2003), surviving an industry attack (Gittell, Cameron, Lim, \& Rivas, 2006), and adoption or resistance of new disruptive BMs (Dewald \& Bowen, 2010).

Resilient firms maintain a broad repertoire of options to effectively respond to challenges (Boisot \& Child, 1999; Lengnick-Hall \& Beck, 2005). Having a flexible inventory of alternatives enables firms to take a different path from that which is the usual (Sutcliffe \& Vogus, 2003), adopt unexpected and timely responses to market shifts (Ferrier, Smith, \& Grimm, 1999), and increase the odds of success (Eisenhardt \& Tabrizi, 1995). Using the resilience perspective, this study will show the repertoire of options available to investment banks. To do that, it is necessary to outline the BMI challenges and dimensions.

\section{BMI challenges}

Firms adjust their BMs in response to challenges (Egfjord and Sund, 2020), antecedents (Amit \& Zott, 2015), and/or barriers (Bocken \& Geradts, 2019). These challenges have been argued to impact organisational outcomes including influencing business performance (Aversa, Furnari, \& Haefliger, 2015), financial sustainability (Santos, Pache, \& Birkholz, 2015), future growth (Gilbert, Eyring, \& Foster, 2012), firm's value (Eyring, Johnson, \& Nair, 2011), competitive advantages (Tallman, Luo, \& Buckley, 2018), and strategic flexibility (George \& Bock, 2011). A full review of the BMI literature undertaken by the authors reveals two internal (challenges top management, and organisational culture) and seven external challenges, namely crises, regulations, client demands, new technologies, competitive pressure, industry, and service providers. Table 1 gives detailed explanation on each of the nine identified challenges. Relevant references are also provided for each challenge.

\section{Activity-based approach}

In BMI research both element-based and activity-based approaches have been used (Clauss, Kesting, \& Naskrent, 2019; Spieth, Schneider, Clauß, \& Eichenberg, 2019). The former is a high abstraction approach that views BMI as a change of BM elements. Although restrictive, this approach has been used to help communicate changes in BMs (e.g. Aversa et al., 2015). However, the latter approach views BMI as a change in BM activities (e.g. Tykkyläinen \& Ritala, 2020). This view goes beyond identifying specific innovation components to by detailing the change in activities performed when adjusting BMs. Based on this view, we use Ramdani, Binsaif, and Boukrami (2019) activity-based framework (Fig. 1). This framework consists of four dimensions and 16 sub-dimensions. Unlike previous conceptualisations that identify the elements associated with BMI, this framework could be used to detail the activity changes within each sub-dimension. 


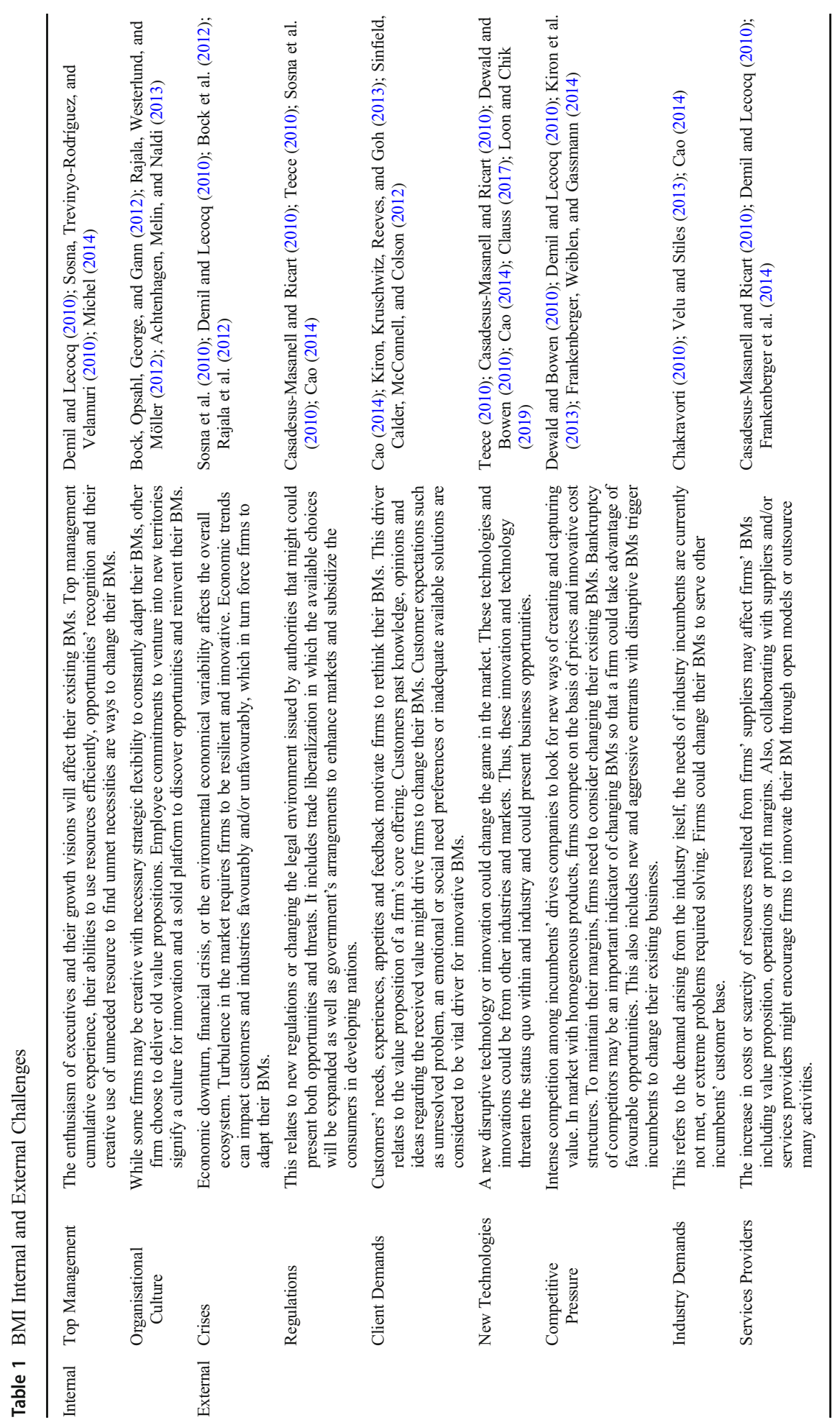




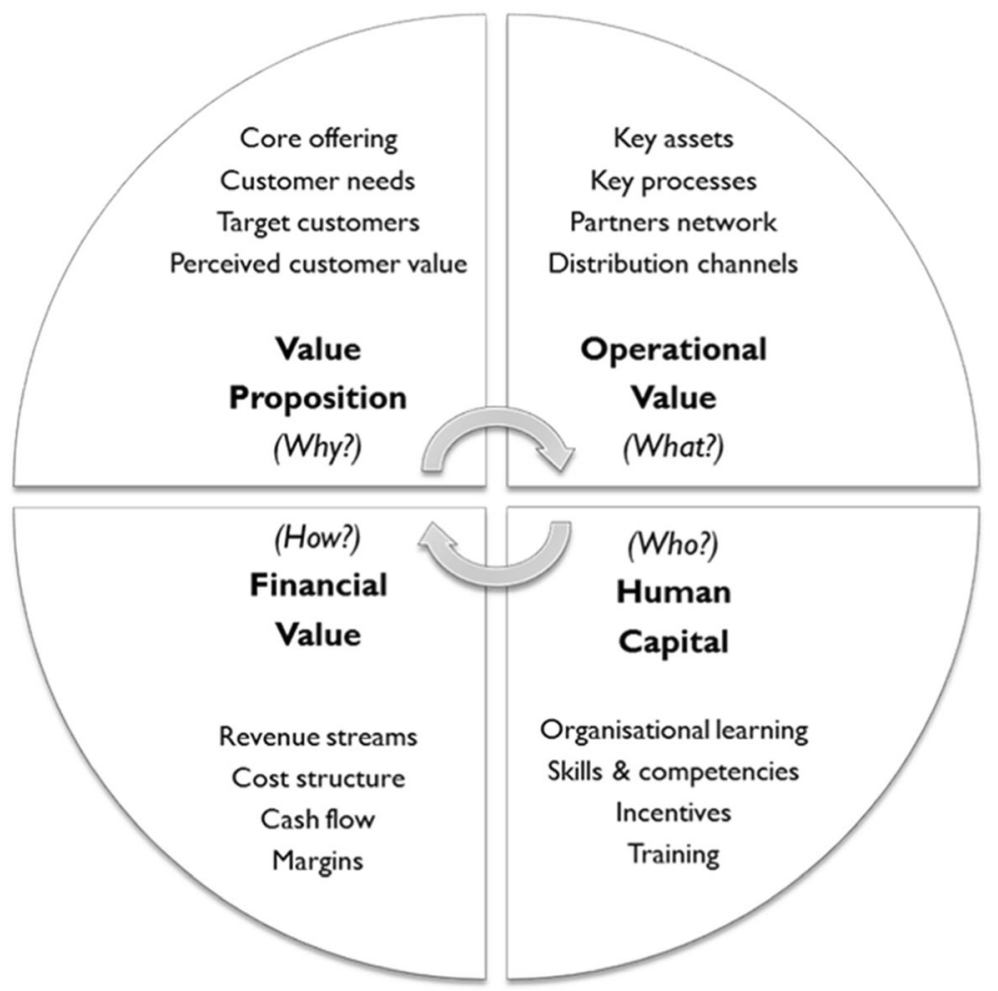

Fig. 1 BMI Framework (Ramdani et al., 2019). Ramdani et al., 2019. Business model innovation: a review and research agenda. New England Journal of Entrepreneurship, 22 (2): 89-108

The four top level dimensions of BM identify different facets of the firm's business. The following is a brief review of these four dimensions:

Value proposition: firms adjust their BM activities by rethinking what a firm sells, exploring new customer needs, acquiring target customers, and ensuring the benefits offered will be perceived by their customers. Prior studies in BMI research show that firms adjust their BMs by exploring various alternatives of core offering (Clauss, 2017), meeting unsatisfied needs in other markets (Eyring et al., 2011), altering activities in the value chain to acquire target customers (Kiron et al., 2013), and articulating a value proposition that is attractive for price-sensitive customers (Wu, Ma, \& Shi, 2010).

Operational Value: firms adjust their BM activities through configuring key assets and sequencing activities to deliver the value proposition, establishing links with key partners and suppliers, and exposing the various means by which a company reaches out to customers. Studies in BMI research highlight that firms can adjust their BMs through integrating various assets (Al-Debei \& Avison, 2010), developing new processes (Mason \& Spring, 2011), forming new partnerships (Clauss, 2017), and adopting new distribution channels (Cao, 2014).

Human Capital: firms adjust their BM activities by experimenting with new ways of doing business, tapping into the skills and competencies (Hock-Doepgen, 
Clauss, Kraus, \& Cheng, 2020) needed for the new BMs through motivating and involving individuals in the innovation process. Prior studies in BMI research show that firms can adjust their BMs through learning from previous experiences (Yunus, Moingeon, \& Lehmann-Ortega, 2010), changing the level of participation in performing the activities (Sorescu et al., 2011), adopting different compensation and incentive policies (Brea-Solís, Casadesus-Masanell, \& Grifell-Tatjé, 2015), and assembling cross-functional teams (Michel, 2014).

Financial Value: firms adjust their BM activities by capturing value through alternative revenue streams, changing the price-setting mechanisms, and assessing the financial viability and profitability. Studies in BMI research highlight that firms can adjust their BMs through introducing new cost structures and revenue models (Clauss, 2017), exploring ways to manage cash-flows, and generating more profit (Sorescu et al., 2011).

\section{Research method}

In order to explore how investment banks adjust their BMs, this study employs a qualitative approach (Yin, 2014). Multiple in-depth case studies are adopted because research in this field is still in its infancy and researchers are seeking new perspectives (Eisenhardt, 1989). Purposive sampling was used to select investment banks that operate all four divisions (i.e. Asset Management, Brokerage, Investment Banking, and Custody Services). As a result, our final sample is 10 fully-licenced investment banks operating in Saudi Arabia.

To ensure the trustworthiness, the authors addressed credibility, transferability, dependability and confirmability based on the criteria developed by Guba (1981). Credibility refers to the internal validity of the data. This was established through the use of triangulation. Primary data collected through semi-structured interviews was verified with the available secondary data (annual reports, financial statements, websites, and brochures). Transferability refers to external validity, which was achieved through the audio recording and transcription of interviews as well as through the purposeful sampling to collect the data from various top management positions where participants included chairman, executives, heads of division and heads of department. Dependability refers to reliability, which was established through ensuring that participants reflect on their experiences covering events that occurred up to 3 years prior to the interviews as well as recent events. Finally, confirmability refers to the objectivity of the data, which was achieved through independently auditing the findings, comparing and refining the interpretations among the authors.

Semi-structured interviews were conducted with participants that had key positions in all four divisions (see the Appendix - Table 6). The participants were asked questions on their banks' goals and strategy, followed by a set of questions focusing on BM activities relating to value proposition, operational value, human capital and financial value, and questions on the their responses to current internal and external challenges. Interviews were recorded and transcribed to develop the full cases. The data was triangulated (Jick, 1979; Gibbert, Ruigrok, \& Wicki, 2008) by cross checking the data with internal documents and publicly available information including the Capital Market Authority (CMA), the Saudi Arabian Monetary Authority (SAMA), the Saudi 
Stock Exchange (Tadawul) and the Ministry of Finance. In total, we conducted 29 interviews, each of which lasted between 46 and $140 \mathrm{~min}$.

Using the validated transcripts, case studies were compiled for each investment bank. Then, the data was coded by two researchers independently (Mayring, 2014). After that, each case was analysed using thematic content analysis to explore how firms adjust their BMs. By analysing the content relating to challenges and the associated changes in activities, the authors were able to link what makes firms change their BMs and how they adjust them. Cross-case analysis (Eisenhardt, 1989) was conducted with two researchers present looking at comparing BMs as well as the challenges and activity changes for each division. The researchers went through several iterations between literature, data and findings until a consistent map was drawn for all BMs. Using the resilience perspective, a repertoire of activities was developed to show all possible activity changes.

\section{Findings}

One of the main findings of this paper is a map that describes the various options available to investment banks to respond to internal and external challenges. Table 2 presents this repertoire of specific activities for all four divisions. The first column shows the BM four dimensions starting with value proposition. The second column shows the four subdimensions for each of the four dimensions. For instance, the first sub-dimension for Operational Value is "Key Assets". The remaining four columns show the actual activities available as a means to respond by adjusting their BM to potential challenges. For example, a Brokerage division under the "Distribution Channels" sub-dimension has four activities (online, mobile, direct calls and branches). This means that if an investment bank identifies that a threat can best be dealt with from the 'Operational Value-Distribution Channels' side, it can use the online activity alone or in combination with the other three tools (mobile, direct calls and branches). Of course, the managers can see a solution as a combination of many dimensions, sub-dimensions and activities.

Table 2 reveals three important aspects of resilience. First, we note the richness and diversity of activities that can help BMs to navigate through difficult terrain. Although some cells (as represented by an individual cell in the table) have one or two activities only, the vast majority of cells contain five activities. The second aspect is the specificity of various activities to the division and BM sub-dimension. Except from a single case (Direct communication under "Perceived Customer Value"), activities do not repeat across divisions or across sub-dimensions. The third aspect is that some divisions have a richer set of activities than others. The highest is Asset Management with 59 activities, followed by Investment Banking and Brokerage with 49 and 46 activities respectively. Custody Services has the least activities, with 31 activities only.

Table 3 summarises the main findings of this paper. The rows of the table show the BM dimensions and sub-dimensions that have been impacted. The columns show the challenges influencing each of the four divisions. Finally, the cells show whether, for a particular cross between BM sub-dimension and challenge, the firm uses activities intensively, moderately or not at all. In the following, we focus only on the most utilised activities.

We begin by highlighting the type of challenges to which divisions are subjected to. First, different divisions have different types and numbers of challenges. For example, the Asset Management and Investment Banking divisions have the highest number of challenges (five each). Custody Services has the least challenges with two only. The 


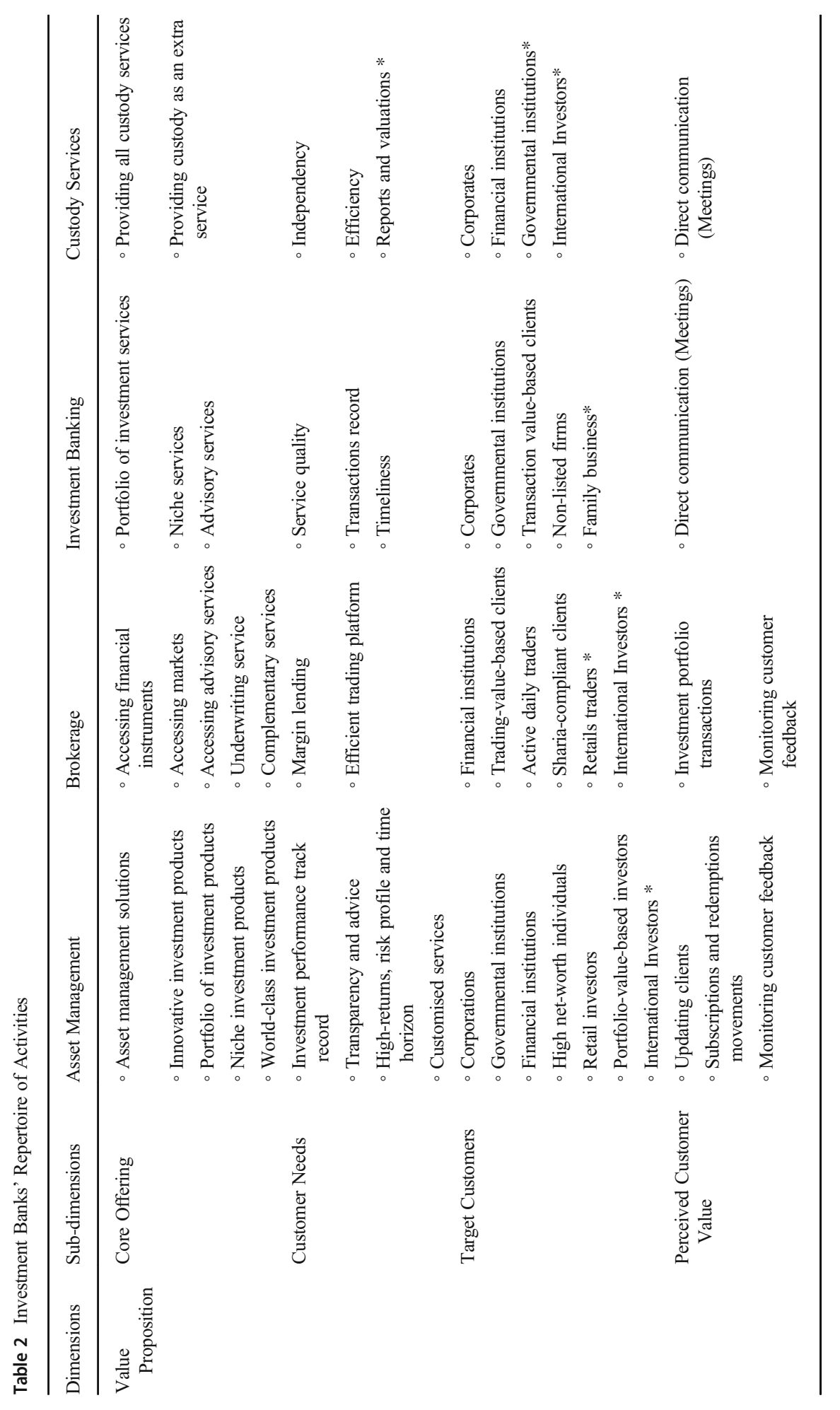




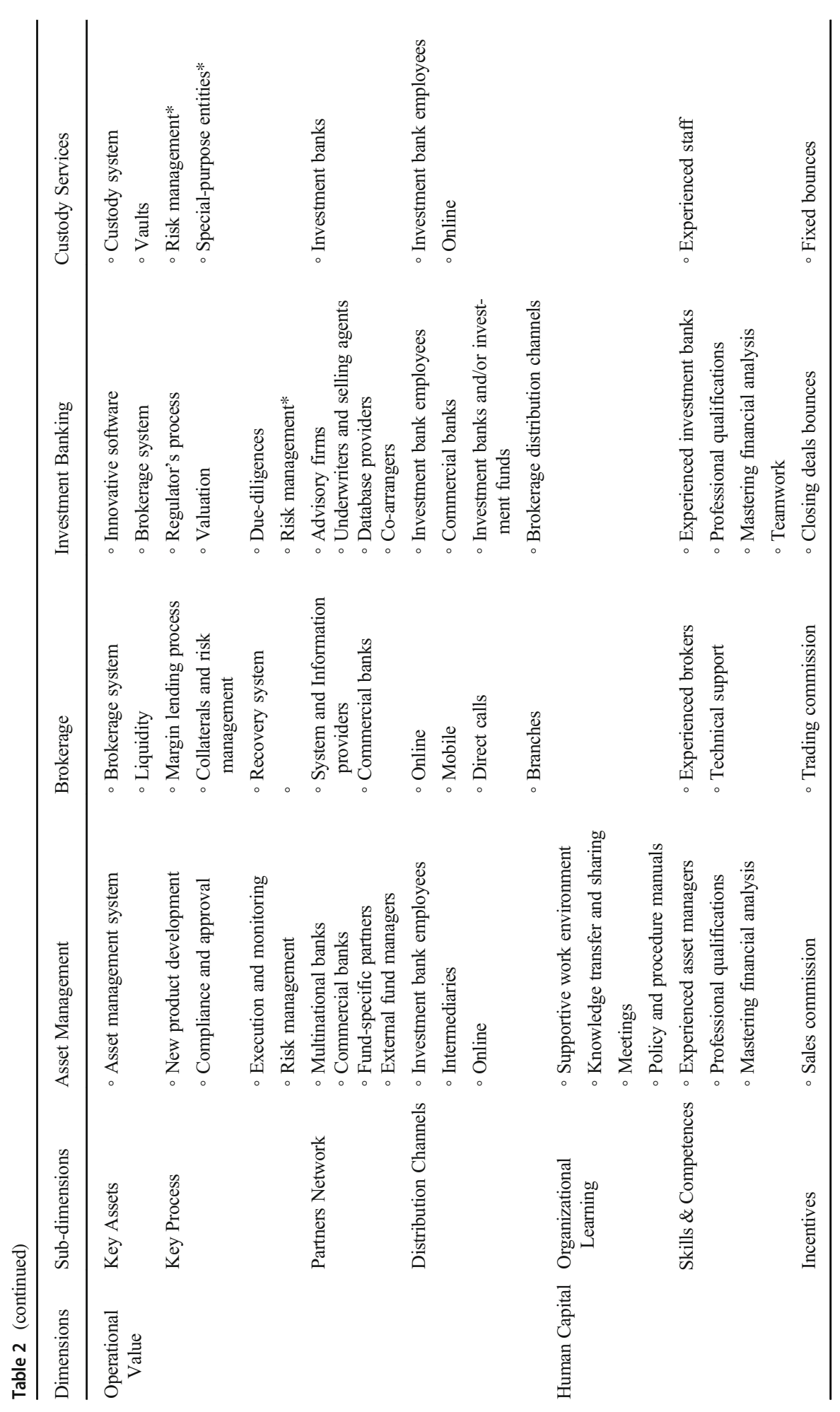




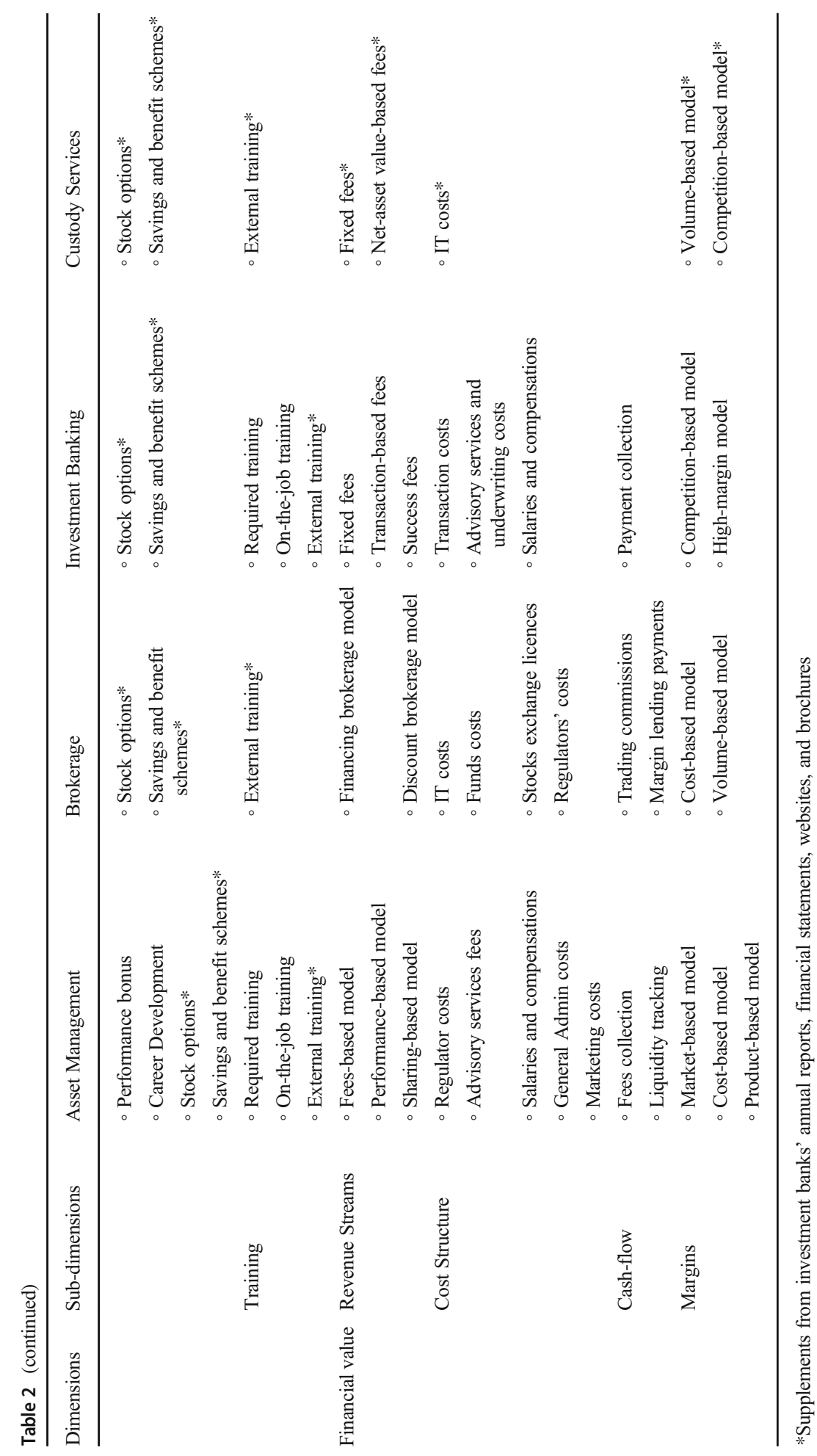


Table 3 Challenges and BMI in All Divisions

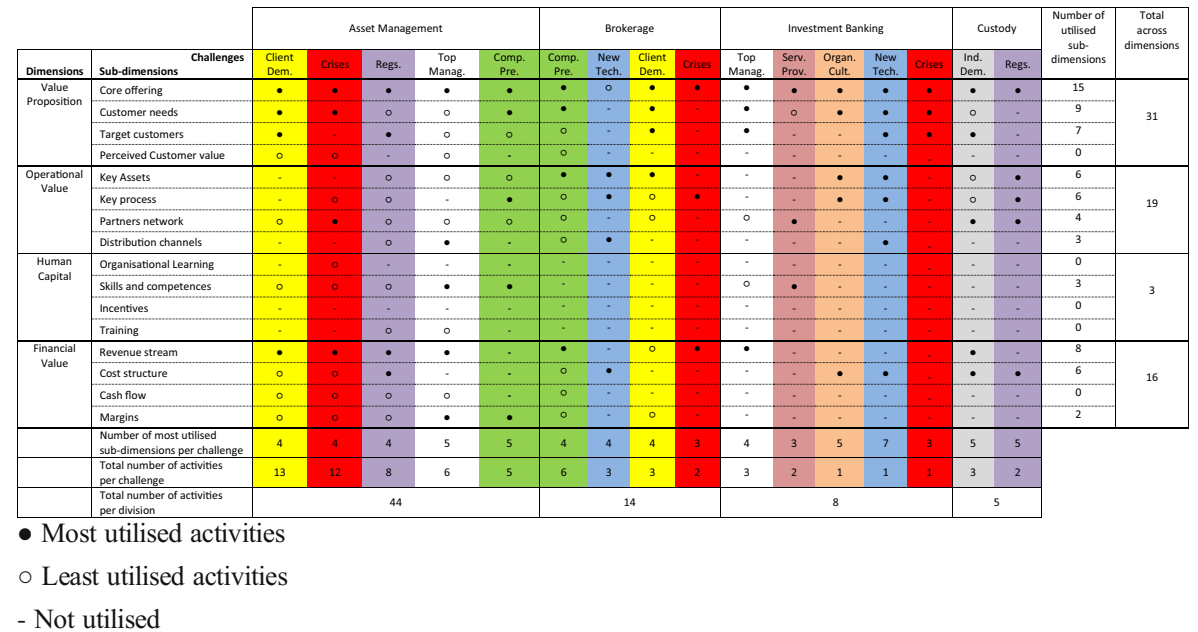

type of challenges varies across the four divisions, with two divisions sharing no more than two types of challenges. For example, Asset Management and Brokerage share "Client Demands" which no other division has. There is one exception. The "Crises" challenge is shared by three divisions, which makes it the most important challenge to investment banks. Second, out of the 16 challenges reported by interviewees, only three are internal (shaded columns), and these are found in Asset Management and Investment Banking divisions.

The pattern of results shown in Table 3 can be summarised as follows. First, different divisions deploy different sets of activities even for the same challenge. For example, if we take the "Client Demands" challenge, Asset Management uses "Revenue Stream" activity, while Brokerage uses "Key Assets" activities (but they use the same three other activities). Second, different divisions have different intensities of activity. By far the most activities deployed are for Asset Management, which totals 44 different activities. This division outshines the other three divisions, with the closest being Brokerage with 14 activities only.

Third, there is a significant difference as to what dimensions of the BM are given priority in overcoming the various challenges. Here we notice one dominant BM dimension and two dominant sub-dimensions. The most important dimension is Value Proposition with 31 sub-dimensions involved throughout the firm. Operational and Financial Value dimensions are also important with 19 and 16 sub-dimensions respectively. The human capital dimension is virtually inexistent, having only 3 out of the possible 64 sub-dimensions involved.

The most important sub-dimension is "Core Offering" which is involved in 15 out of the possible 16 challenges throughout the firm. The second and fourth highest subdimensions are "Customer Needs" and "Target Customers" with 9 and 7 challenges respectively. All three sub-dimensions form the core "Value Proposition" dimension. The third most important sub-dimension is "Revenue Stream", with involvement in 8 challenges. The table also reveals that there are five unimportant sub-dimensions (zero challenges), and three weak sub-dimensions ( 3 or 2 challenges in total). 
Overall, depending on the challenge faced, investment banks respond by adjusting their BM through deploying alternative combinations of activities from the repertoire. In Asset Management division, Table 3 shows that investment banks respond to the six challenges by altering eight sub-dimensions with a total of 44 activities.

To obtain further insights as to what kind of specific activities are used by investment banks, we produce detailed activity responses to the challenges faced by each division. We will focus here on presenting the activity responses to challenges in the Asset Management division (highlighted in Table 4). Activity responses to challenges faced by other divisions are included in the Appendix. Within the Asset Management division, two main sub-dimensions are dominant, namely the "Core Offering" and "Revenue Stream". Within "Core Offering”, innovative investment is used as an activity against all five threats, whereas under "Revenue Stream" the fees-based model is dominant.

In the Asset Management division, investment banks respond to five challenges with a repertoire of activities. Top management push asset managers to create new investment products and alter both current revenue streams and overall margins. Asset managers respond to clients' demands by creating new investment products to meet needs for new categories of customers, and adopting a new revenue model that is based on sharing the returns. In response to financial crisis, asset managers created a new offering with low margins and low returns to meet the demands of the new customer base that have fixed income and low-risk profile. To adhere to regulations and maintain the division's performance, asset managers created new funds to target international investors and modified the fee structure of some funds to absorb the regulator's imposed costs. Finally, asset managers responded to competitive pressure by hiring new asset managers, expanding the portfolio of investment products, charging lower fees for niche investment products.

For the remaining divisions, the repertoire of utilised activities is detailed in the Appendix (Tables 8, 9, 10). The Brokerage division responds to four challenges, namely competitive pressure, new technologies, client demands, and crises. As the competition intensifies this division invests in its brokerage system to approve margin lending (loans for trading) online, and deploy multi-brokerage models where clients are charged either through trading commissions or lending revenues. The technology challenges were dealt with by improving the brokerage system to allow clients to trade via online platforms or through smartphones. Investment banks also deployed multi-channel communication tools as a means to change some of the key processes such as opening online accounts. This led to reducing the staff and branch costs, but increased the IT costs. Clients' demands were responded to by improving their brokerage systems to facilitate access and transactions for active traders. After the 2008 financial crisis, investment banks introduced margin lending to encourage trading. However, after the market stabilised, investment banks changed the parameters for margin lending to increase returns by charging trading commissions.

Investment Banking divisions face both internal and external challenges, including top management, service providers, organisational culture, new technologies, and crises. The response to top management challenges led to diversifying portfolio of investment services to attract new customers internationally such as corporates and government institutions interested in buying family-owned businesses. This meant that revenue streams (such as fixed, transaction-based, and success fees) were negotiated depending on the deal. One of the teams responsible for IPOs suggested changing a labour intensive process. A software was developed to automate the process, which led to reducing staff costs, quickening the process of delivering services, and finishing the deal faster for 


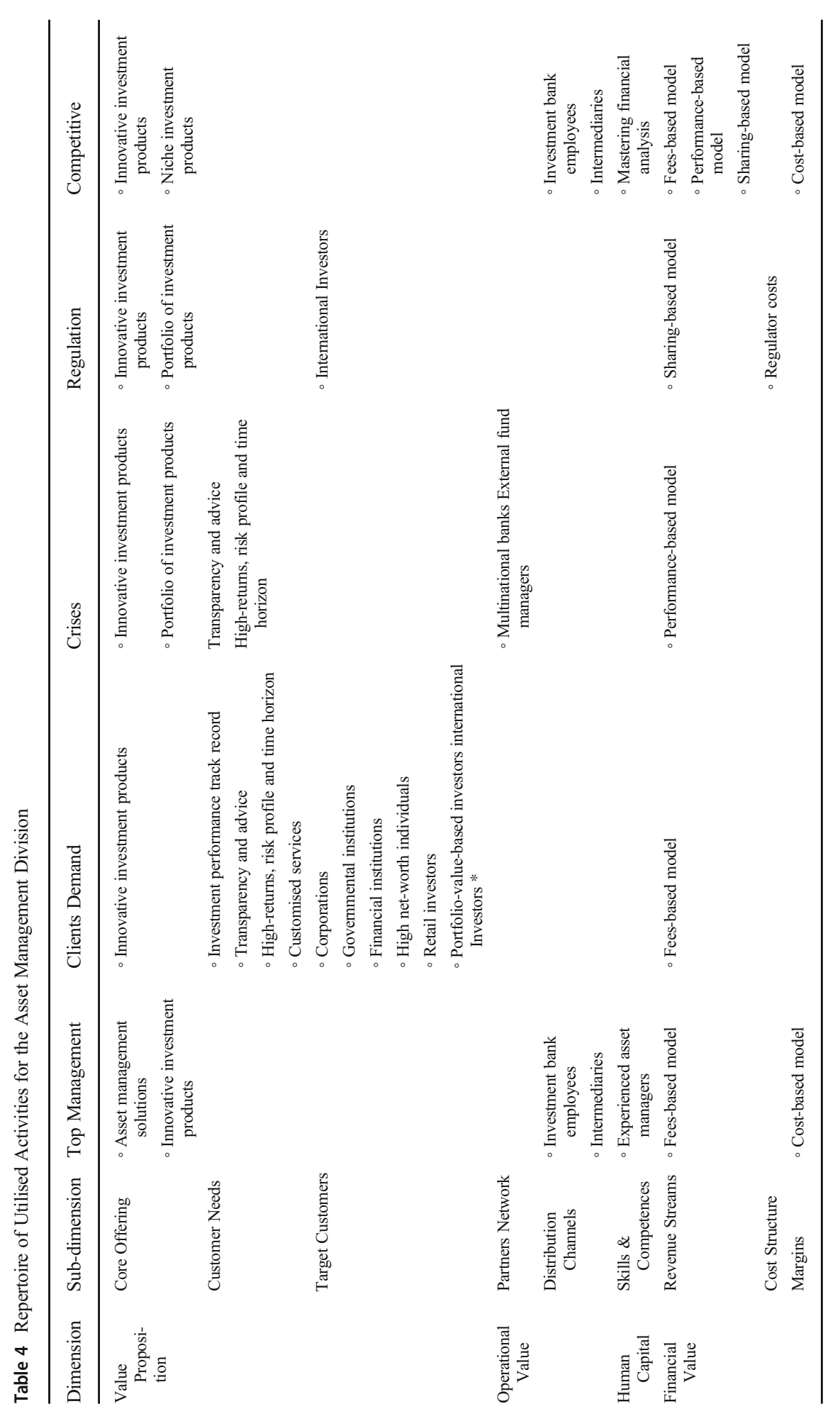


corporates in order to go public. Because banking advisory services depends on the participation of other parties such as accountants, legal firms, commercial banks, and underwriters, services may not be delivered in a timely fashion. Thus, in response to service providers' challenges, Investment Banking divisions change their partnerships with legal firms and hire experienced investment banks that are able to deliver reliable services. The response to new technologies focused on new online and mobile distribution channels to make it easier for clients to access services, monitor their progress, and provide them with reports. Finally, during times of fluctuations in the market, this division focuses more on advisory services where non-listed firms prepare their IPOs or preferred private equities and only go public if the market conditions are favourable.

In Custody Services division, investment banks respond to two external challenges, namely industry demands and regulations. Custody Services division responded to industry demands by offering their services to non-listed firms, investment banks, and mutual investment funds. Technical investment banks partners were established to perform custody services at a lower cost and deliver these services to other banks bringing in new revenues. Finally, to adhere to new local regulations, investment banks were forced to assign an independent custodian to carry out safekeeping and administration, which meant that some banks were consuming these services locally through other investment banks or outsourcing these activities to an international partner. By improving their custody systems, investment banks incurred new IT costs.

To assess the performance of each division for 2016 and 2017, revenue growth data is highlighted in Table 5. Looking at the cumulative growth for each division, the data suggest that divisions responding to only external challenges tend to sustain their performance levels as highlighted in Brokerage and Custody Services divisions. However, divisions responding to both internal and external challenges (i.e. Asset Management and Investment Banking) tend to bounce back in the Asset Management division and increase growth substantially in the Investment Banking division.

\section{Discussion}

Firms respond to internal and external challenges through adaptation and/or resilience. The adaptation perspective focuses on responding to external challenges (Saebi et al., 2017), whereas the resilience perspective focuses on responding to both internal and external challenges. All divisions responded to external challenges. This may explain the focus of previous studies on responding to external challenges through adaptation. However, this study shows that resilience can be achieved by responding to both internal and external challenges. As a result, revenue growth bounced back in the Asset Management divisions, and increased substantially for Investment Banking divisions.

In their response to internal challenges, both divisions responded to top management. Asset managers withheld periodical meetings to discuss performance and review new trends in the industry in order to develop new investment products. In the Investment Banking division, financial advisory and arrangements were delivered with guarantees from the top in terms of execution and professionalism. Different management challenges are posed when carrying out BMI (Foss \& Saebi, 2017). Moreover, Investment Banking responded to the challenge of organisational culture. By embracing an innovative culture, Investment 
Table 5 Revenue Growth for All Four Divisions

\begin{tabular}{|c|c|c|c|c|c|c|c|c|}
\hline \multirow[t]{2}{*}{ Bank } & \multicolumn{2}{|c|}{ Asset Management } & \multicolumn{2}{|c|}{ Brokerage } & \multicolumn{2}{|c|}{ Investment Banking } & \multicolumn{2}{|c|}{ Custody Services } \\
\hline & 2016 & 2017 & 2016 & 2017 & 2016 & 2017 & 2016 & 2017 \\
\hline A & $-29 \%$ & $64 \%$ & $-31 \%$ & $-22 \%$ & $-66 \%$ & $-50 \%$ & & \\
\hline B & $-83 \%$ & $92 \%$ & & & $21 \%$ & $-31 \%$ & & \\
\hline $\mathrm{C}$ & $-38 \%$ & $-23 \%$ & $-35 \%$ & $-34 \%$ & $-87 \%$ & $825 \%$ & & \\
\hline $\mathrm{D}$ & $5 \%$ & $-15 \%$ & $-35 \%$ & $-89 \%$ & & & & \\
\hline $\mathrm{E}$ & & & & & & & & $7 \%$ \\
\hline $\mathrm{F}$ & $97 \%$ & $76 \%$ & $-12 \%$ & $-20 \%$ & $73 \%$ & $347 \%$ & $100 \%$ & $31 \%$ \\
\hline G & $-12 \%$ & $2 \%$ & $-31 \%$ & $-25 \%$ & $79 \%$ & $0.2 \%$ & $56 \%$ & $18 \%$ \\
\hline $\mathrm{H}$ & $-21 \%$ & $15 \%$ & $10 \%$ & $-26 \%$ & $34 \%$ & $553 \%$ & & \\
\hline I & $34 \%$ & $24 \%$ & $-23 \%$ & $-24 \%$ & $122 \%$ & $-68 \%$ & $100 \%$ & $27 \%$ \\
\hline $\mathrm{J}$ & & & $-37 \%$ & $23 \%$ & & & & \\
\hline Cumulative Growth & $-45 \%$ & $235 \%$ & $-195 \%$ & $-216 \%$ & $176 \%$ & $1575 \%$ & $256 \%$ & $83 \%$ \\
\hline
\end{tabular}

Banking division was able to capitalise on new ideas emerging from internal teams. In short, creative culture has positive effects on firms undertaking BMI (Bock et al., 2012).

In their response to internal and external challenges, investment banks maintain a broad repertoire of activities that are used to adjust their BMs. Firms keep a broad repertoire of options to overcome challenges (Boisot \& Child, 1999; Lengnick-Hall \& Beck, 2005). Although previous studies claim that firms are able to respond to challenges through continuously adjusting their BMs (Landau et al., 2016), it is not clear how such a continuous adjustment of BMs takes place. We demonstrate how investment banks continuously adjust their BM through deploying alternative combinations of activities from the repertoire in response to specific internal and/or external challenge.

To adjust their BMs, investment banks modify a combination of activities. Previous studies in BMI have shown that firms adjust their BMs by changing a single component to replacing the entire BM (Saebi et al., 2017). This study shows that investment banks deploy a variety of activities. While the most important set of activities are found within the value proposition, followed by the operational value and the financial value dimensions, the lowest activity changes occur in the human capital dimension. This could be due to the challenges faced, the nature of the industry, and the context. This study shows that investment banks tend to mainly respond to external challenges including clients' demands, crises and competitive pressure. In their response, investment banks focus more on rethinking their value proposition through expanding their core offering and meeting customer needs. Previous studies have focused on modifying the value proposition due to external challenges (e.g. Demil \& Lecocq, 2010). Moreover, the nature of the financial services industry could have influenced which activity changes investment banks must focus on. The operational value and financial value activities remain less changeable than value proposition due to the maturity of the industry as well as the stringency of the regulatory environment. Also, it is a well-known practice that investment banks attract the highest talents because they can afford them. This may explain why human capital activity changes are the lowest changed compared to other activities. According to Chivers (2011), training in investment banks tend to be more "informal and on-the-job in nature". He argues that this informal learning 
was "ad hoc, poorly recorded, and limited in scope". Also, he claims that investment bankers prefer learning by doing. This may explain why human capital activity changes are the lowest changed compared to other activities. Previous studies show the particularity of certain industries (e.g. Aversa et al., 2015). Finally, the context of this study might have influenced activity changes. This study is conducted in an emerging economy, where the BMs are usually replications of existing BMs in developed economies rather completely new BMs. This could explain why activity changes focus more on the value proposition to adapt their replicated BMs (Landau et al., 2016).

\section{Theoretical implications}

By revealing how investment banks adjust their BMs in response to internal and external challenges, this study makes at least four contributions to BMI literature. First, it confirms that firms adjust their BMs not only in response to external challenges (Amit \& Zott, 2015), but also in response to internal challenges (Teece, 2018). In this paper, we summarise and list the internal and external challenges that influence firms to change their existing BMs. Also, we show that resilience can be achieved by responding to both internal and external challenges. Second, this study provides important insights into how firms change their existing BM using a repertoire of activities. Using the resilience perspective, this study provides insight into how firms adjust their BMs by altering specific activities, an area that has not been sufficiently covered. This study captures activity changes by empirically examining the BMI framework. Third, this study brings together internal and external perspectives of the BMI literature, and provides evidence on the challenges and the associated activity changes for each of the four investment banking divisions. Fourth, this study adds evidence to industry-focused BMI by examining BMI in an understudied industry context (i.e. investment banks).

\section{Managerial implications}

This study has several implications for senior executives, analysts and regulators. It provides senior executives with a repertoire of activities that can be used to adjust their BMs. The repertoire can be used in conjunction with internal and external challenges to navigate BMI. This repertoire can be used not only by executives working in investment banks, but also by executives in other sectors to develop their own repertoire of potential BMs. Moreover, this study provides analysts and investors with a tool to help them understand investment banks BMs. The repertoire could be used by investors and financial analysts to complement their financial, industry and company analyses. By using this repertoire, analyst could demystify the complexity of activities, identify risks for each activity, and rationalise the different financial and operational performances. Furthermore, this repertoire could be used by regulators to legislate based on informed understanding of activity changes. This repertoire could help regulators navigate activity changes, communicate these changes with investment banks, and legislate accordingly.

\section{Limitations and future research}

Apart from the typical limitations that apply to qualitative studies, we highlight three areas for future research. First, this study fills a significant gap in our understanding of the internal 
challenges (Foss \& Saebi, 2017) by demonstrating that firms need to respond to top management and organizational culture. Future research should further unravel other internal challenges such as organisational capabilities. Second, this study demonstrates that investment banks achieve resilience through continuously adjusting their BMs by maintaining a repertoire of activity changes. Future studies should explore flexible repertoires of options in other industries and how they compare to the findings of this study. Also, it will be interesting to track the sequence of activity changes, which was not captured in our study. Another avenue for future research is to investigate the levels of resilience among a group of firms facing similar internal and external challenges. Third, although this study showed how firms adjust their BMs in response to internal and external challenges and the associated performance levels for divisions, more research is needed to show activity changes and link them to performance levels. It would be interesting to further examine the association between BM changes and firm performance.

\section{Conclusion}

The aim of this study was to explore how investments banks adjust their BMs in response to internal and external challenges. Using the resilience perspective, case evidence from ten investment banks operating in the largest financial market in the Middle East was qualitatively analysed. The findings of this study suggest that investment banks adjust their BM through continuous activity changes in response to internal and external challenges. To overcome challenges, investment banks maintain a broad repertoire of activities that are used to adjust their BMs. Investment banks respond by adjusting their BMs through deploying alternative combinations of activities from the repertoire in response to specific internal and/or external challenges. In their response to internal and external challenges, investment banks deploy a variety of activities. While the most important set of activities are related to the value proposition, followed by the operational value and the financial value dimensions, the lowest activity changes occur in the human capital dimension.

Acknowledgements We thank the senior editor Dr. Seung-Hyun Lee and two anonymous reviewers for their insightful and constructive comments.

Availability of data and material (The datasets generated during and/or analysed during the current study are not publicly available due to sharing restrictions, but are available from the corresponding author on reasonable request)

Funding Information Open Access funding provided by the Qatar National Library.

\section{Compliance with ethical standards}

Conflicts of interest/competing interests Not applicable.

Code availability (Custom code is available from the corresponding author on reasonable request)

Consent to participate Informed consent was obtained from all individual participants included in the study.

Consent to publish Not Applicable 


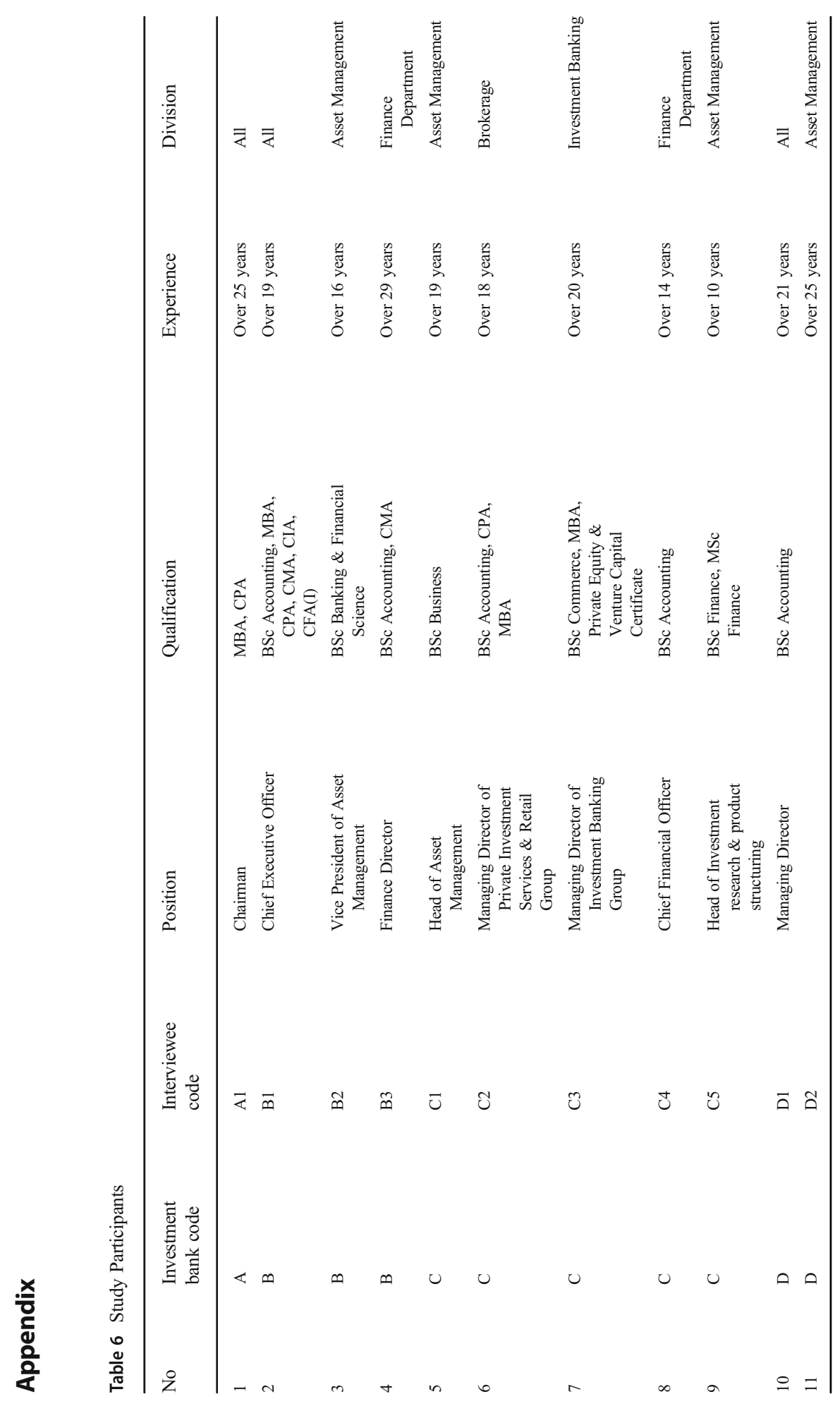




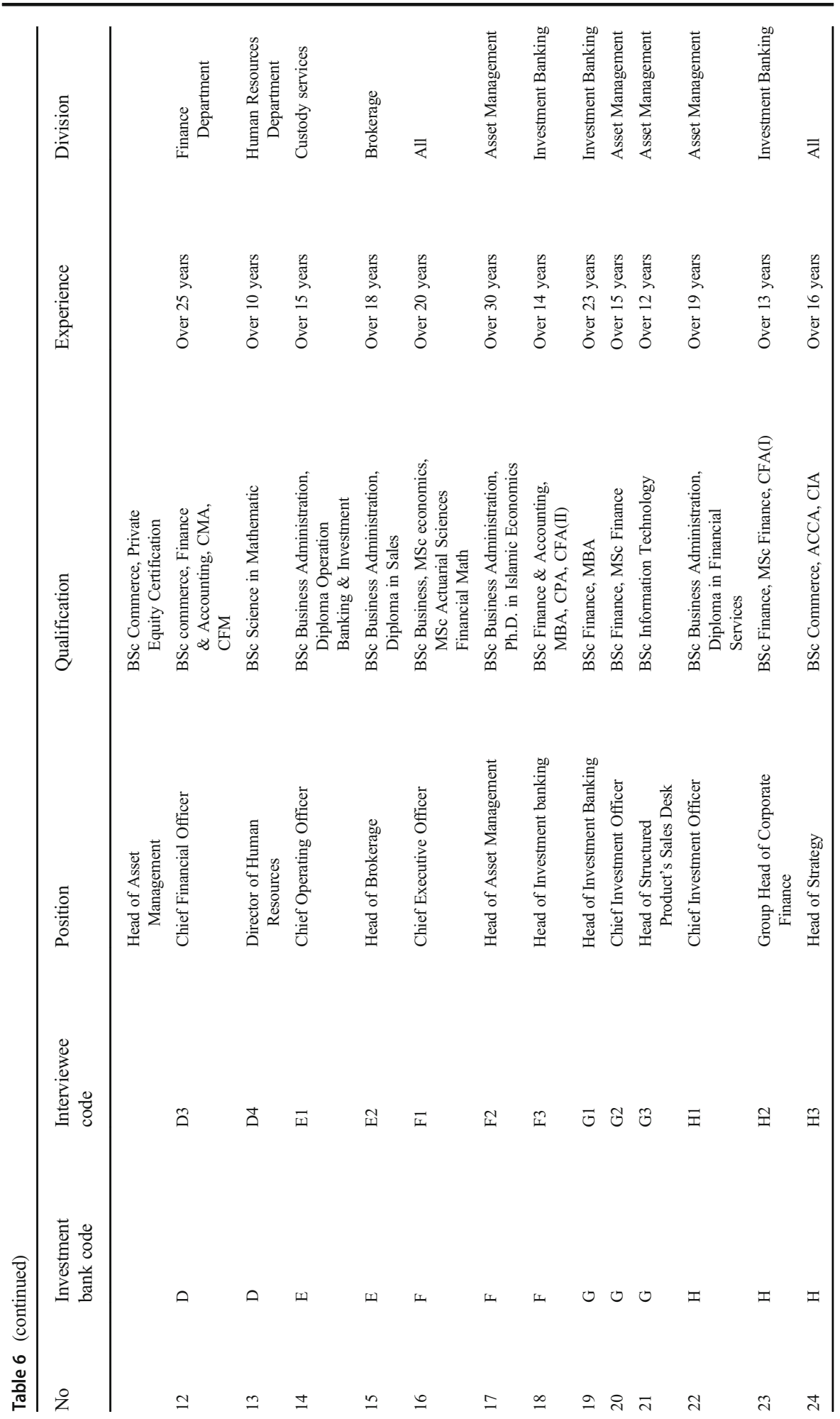




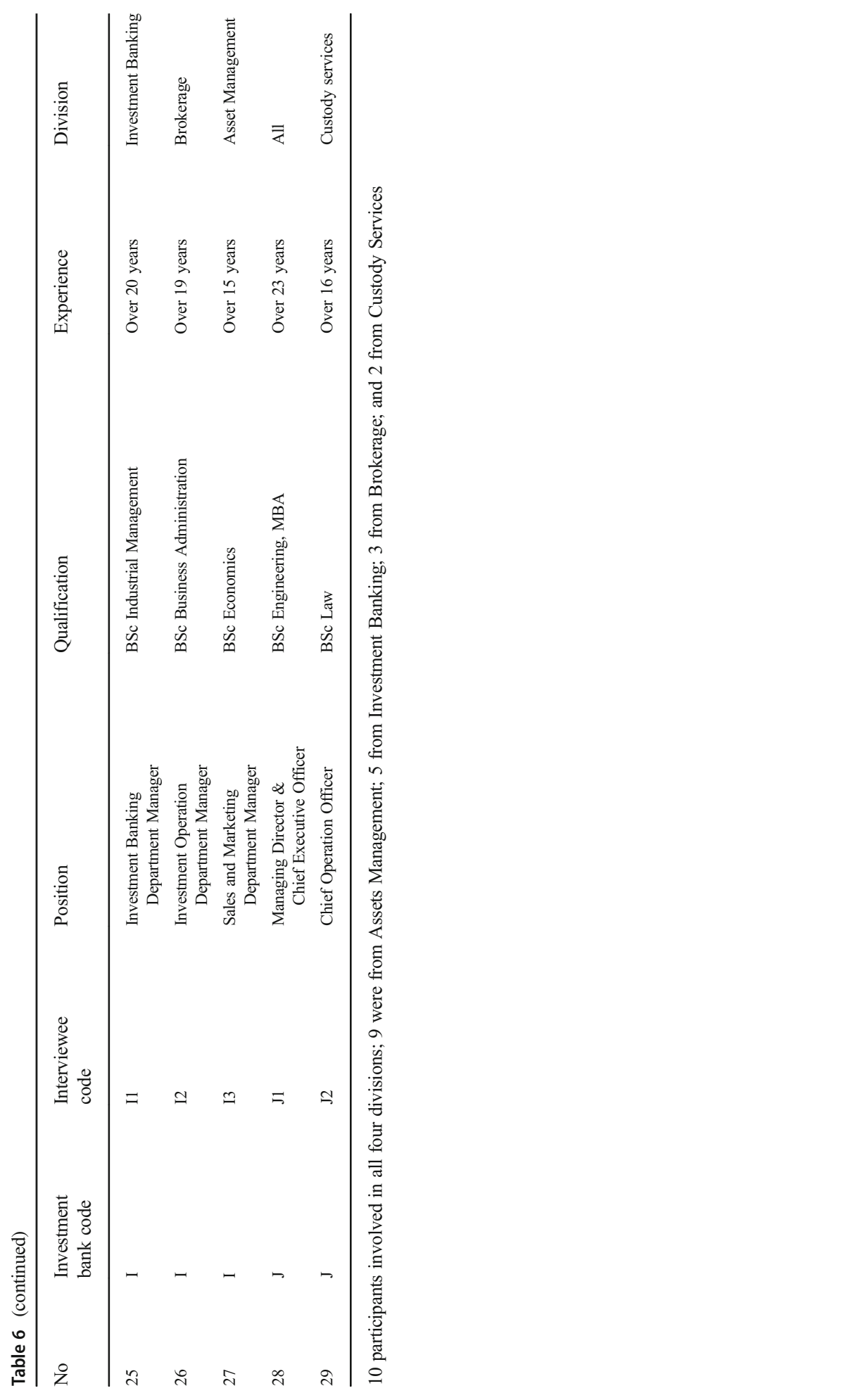


Table 7 Examples of internal and external challenges facing investment banks in Saudi Arabia

\begin{tabular}{|c|c|c|}
\hline \multicolumn{2}{|l|}{ Challenges } & \multirow{2}{*}{$\begin{array}{l}\text { Examples } \\
\text { - Providing employees with space to create new products } \\
\text { - Restructuring the division into two business lines }\end{array}$} \\
\hline Internal & Top Management & \\
\hline & Organisational Culture & $\begin{array}{l}\text { - Building strong, committed and professional teams } \\
\text { - Encouraging and implementing new ideas suggested by teams }\end{array}$ \\
\hline \multirow[t]{7}{*}{ External } & Crises & $\begin{array}{l}\text { - Global financial crisis } 2008 \\
\text { - Saudi stock market crash } 2006 \text { and } 2015\end{array}$ \\
\hline & Regulations & $\begin{array}{l}\text { - CMA opening up of the financial markets to foreign investors } \\
\text { - Amendments of IPO rules } \\
\text { - CMA stop issuing licences for real estate funds } \\
\text { - Forcing investment banks to work with custody firms }\end{array}$ \\
\hline & Client Demands & $\begin{array}{l}\text { - Low-risk products } \\
\text { - Islamic products }\end{array}$ \\
\hline & New Technologies & $\begin{array}{l}\text { - Online trading } \\
\text { - Smartphones' apps trading } \\
\text { - New IPO system }\end{array}$ \\
\hline & Competitive Pressure & $\begin{array}{l}\text { - Offering products with competitive fees } \\
\text { - Increasing discounts in trading commissions } \\
\text { - Offering margins trading }\end{array}$ \\
\hline & Industry Demands & $\begin{array}{l}\text { - Guarantee bank equities } \\
\text { - Custody services to be provided by } \\
\text { - third-parities }\end{array}$ \\
\hline & Services Providers & $\begin{array}{l}\text { - Specialised corporate finance services } \\
\text { - Market studies } \\
\text { - Financial valuations } \\
\text { - Data collection and analysis } \\
\text { - Legal services } \\
\text { - Underwriting services }\end{array}$ \\
\hline
\end{tabular}




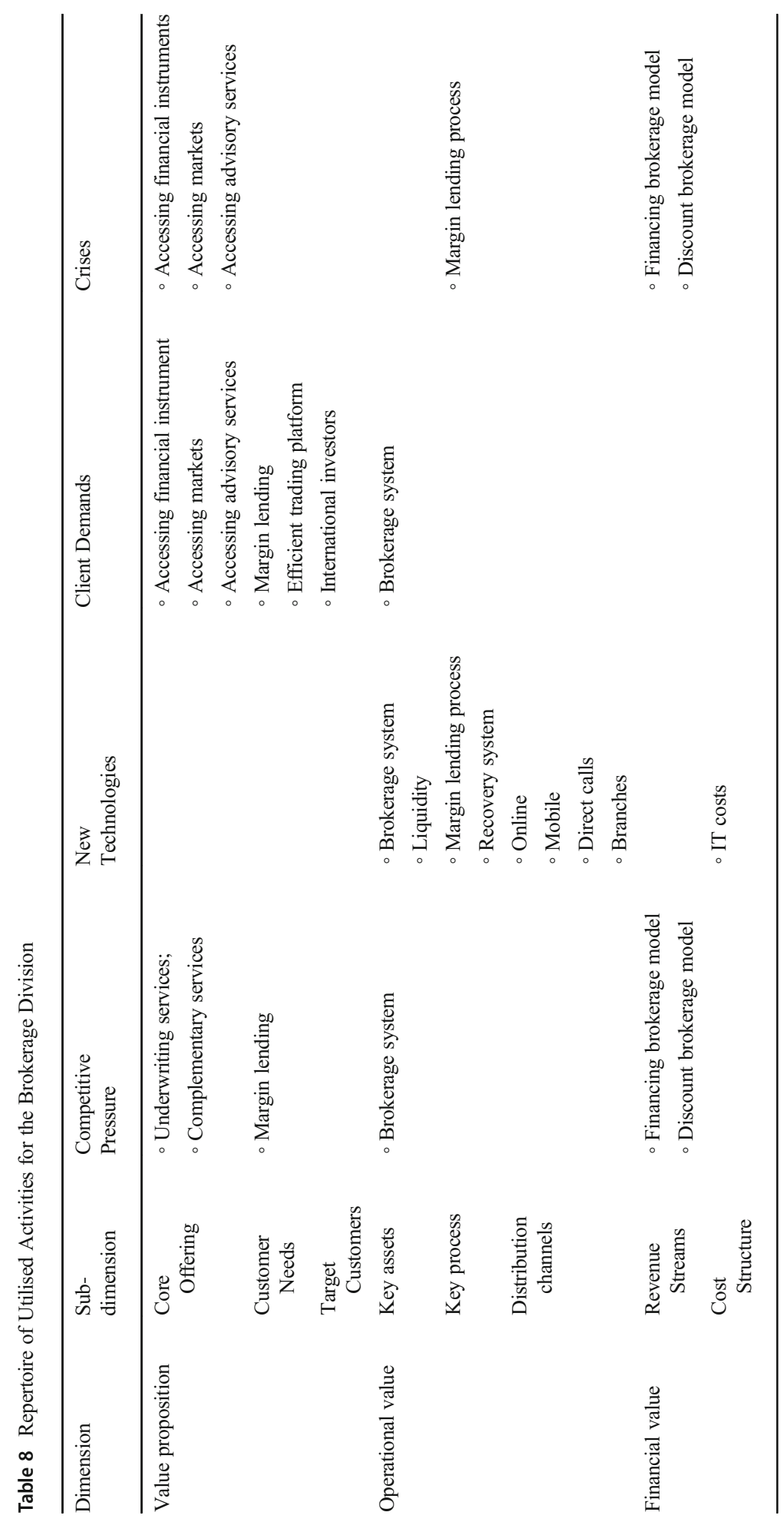




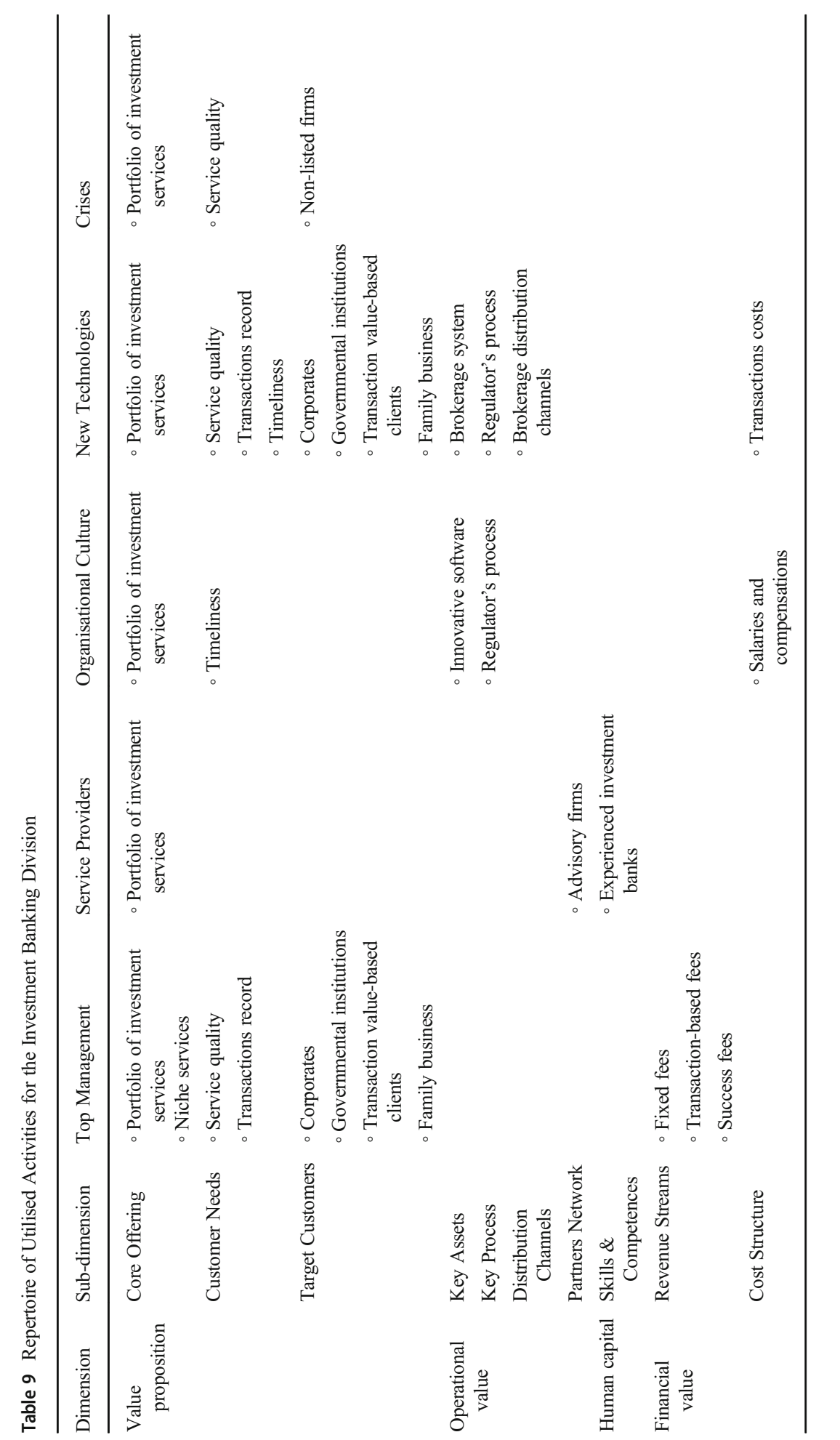


Table 10 Repertoire of Utilised Activities for the Custody Services Division

\begin{tabular}{|c|c|c|c|}
\hline Dimension & Sub-dimension & Industry demands & Regulations \\
\hline $\begin{array}{l}\text { Value } \\
\text { proposition }\end{array}$ & $\begin{array}{l}\text { Core Offering } \\
\text { Customer Needs }\end{array}$ & $\begin{array}{l}\text { - Providing all custody services } \\
\text { - Providing custody as an extra service } \\
\text { - Corporates } \\
\text { - Financial institutions } \\
\text { - International Investors }\end{array}$ & $\begin{array}{l}\text { - Providing all custody } \\
\text { services }\end{array}$ \\
\hline $\begin{array}{l}\text { Operational } \\
\text { value }\end{array}$ & $\begin{array}{l}\text { Key Assets } \\
\text { Key Process } \\
\text { Partners } \\
\text { Network }\end{array}$ & ○Investment banks & $\begin{array}{l}\circ \text { Custody system } \\
\text { - Special-purpose entities } \\
\text { - Investment banks }\end{array}$ \\
\hline Financial value & $\begin{array}{l}\text { Revenue } \\
\text { Streams }\end{array}$ & $\begin{array}{l}\text { - Fixed fees } \\
\text { - Net-asset value-based fees }\end{array}$ & \\
\hline & Cost Structure & $\circ$ IT costs & - IT costs \\
\hline
\end{tabular}

Open Access This article is licensed under a Creative Commons Attribution 4.0 International License, which permits use, sharing, adaptation, distribution and reproduction in any medium or format, as long as you give appropriate credit to the original author(s) and the source, provide a link to the Creative Commons licence, and indicate if changes were made. The images or other third party material in this article are included in the article's Creative Commons licence, unless indicated otherwise in a credit line to the material. If material is not included in the article's Creative Commons licence and your intended use is not permitted by statutory regulation or exceeds the permitted use, you will need to obtain permission directly from the copyright holder. To view a copy of this licence, visit http://creativecommons.org/licenses/by/4.0/.

\section{References}

Achtenhagen, L., Melin, L. \& Naldi, L., 2013. Dynamics of business models-strategizing, critical capabilities and activities for sustained value creation. Long Range Planning, 46(6): 427-442.

Al-Debei, M.M. \& Avison, D., 2010. Developing a unified framework of the business model concept. European Journal of Information Systems, 19(3): 359-376.

Amit, R., \& Zott, C. 2015. Crafting business architecture: The antecedents of business model design. Strategic Entrepreneurship Journal, 9(4): 331-350.

Aspara, J., Hietanen, J. \& Tikkanen, H., 2010. Business model innovation vs replication: financial performance implications of strategic emphases. Journal of Strategic Marketing, 18(1): 39-56.

Aversa, P., Furnari, S. \& Haefliger, S., 2015. Business model configurations and performance: A qualitative comparative analysis in Formula One racing, 2005-2013. Industrial and Corporate Change, 24(3): 655676.

Bock, A.J., Opsahl, T., George, G. \& Gann, D.M., 2012. The effects of culture and structure on strategic flexibility during business model innovation. Journal of Management Studies, 49(2): 279-305.

Bocken, N.M., \& Geradts, T.H., 2019. Barriers and drivers to sustainable business model innovation: Organization design and dynamic capabilities. Long Range Planning, 101950. https://doi.org/10.1016/j. lrp.2019.101950.

Boisot, M. \& Child, J., 1999. Organizations as adaptive systems in complex environments: The case of China. Organization Science, 10(3): 237-252.

Brea-Solís, H., Casadesus-Masanell, R. \& Grifell-Tatjé, E., 2015. Business Model Evaluation: Quantifying W almart's Sources of Advantage. Strategic Entrepreneurship Journal, 9(1): 12-33. 
Cao, L., 2014. Business model transformation in moving to a cross-channel retail strategy: A case study. International Journal of Electronic Commerce, 18(4): 69-96.

Casadesus-Masanell, R. \& Ricart, J.E., 2010. From strategy to business models and onto tactics. Long Range Planning, 43(2-3): 195-215.

Chakravorti, B. 2010. Finding Competitive Advantage in Adversity. Harvard Business Review, 88(11): 102108.

Chivers, G. 2011. Supporting informal learning by traders in investment banks. Journal of European Industrial Training, 35(2): 154-175.

Clauss, T. 2017. Measuring business model innovation: Conceptualization, scale development, and proof of performance. R\&D Management, 47(3): 385-403.

Clauss, T., Kesting, T., \& Naskrent, J. 2019. A rolling stone gathers no moss: the effect of customers' perceived business model innovativeness on customer value co-creation behavior and customer satisfaction in the service sector. R\&D Management, 49(2): 180-203.

Cozzolino, A., Verona, G., \& Rothaermel, F. T. 2018. Unpacking the disruption process: New technology, business models, and incumbent adaptation. Journal of Management Studies, 55(7): 1166-1202.

Crotty, J., 2009. Structural causes of the global financial crisis: a critical assessment of the 'new financial architecture'. Cambridge Journal of Economics, 33(4): 563-580.

Demil, B. \& Lecocq, X., 2010. Business model evolution: in search of dynamic consistency. Long Range Planning, 43(2-3): 227-246.

Dewald, J. \& Bowen, F., 2010. Storm clouds and silver linings: Responding to disruptive innovations through cognitive resilience. Entrepreneurship Theory and Practice, 34(1): 197-218.

Egfjord, K.F.H. \& Sund, K.J., 2020. Do you see what I see? How differing perceptions of the environment can hinder radical business model innovation. Technological Forecasting and Social Change, 150: 119787. https://doi.org/10.1016/j.techfore.2019.119787.

Eisenhardt, K.M., 1989. Building theories from case study research. Academy of Management Review, 14(4): 532-550.

Eisenhardt, K.M. \& Tabrizi, B.N., 1995. Accelerating adaptive processes: Product innovation in the global computer industry. Administrative Science Quarterly, 40(1): 84-110.

Eyring, M.J., Johnson, M.W. \& Nair, H., 2011. New business models in emerging markets. Harvard Business Review, 89(1-2): 88-95.

Ferrier, W.J., Smith, K.G. \& Grimm, C.M., 1999. The role of competitive action in market share erosion and industry dethronement: A study of industry leaders and challengers. Academy of Management Journal, 42(4): 372-388.

Finlan, A. 2003. The gulf war of 1991. London: Osprey.

Foss, N.J. \& Saebi, T., 2017. Fifteen years of research on business model innovation: How far have we come, and where should we go?. Journal of Management, 43(1): 200-227.

Frankenberger, K., Weiblen, T. \& Gassmann, O., 2014. The antecedents of open business models: an exploratory study of incumbent firms. R\&D Management, 44(2): 173-188.

Futterer, F., Schmidt, J., \& Heidenreich, S. 2018. Effectuation or causation as the key to corporate venture success? Investigating effects of entrepreneurial behaviors on business model innovation and venture performance. Long Range Planning, 51(1): 64-81.

George, G. \& Bock, A.J., 2011. The business model in practice and its implications for entrepreneurship research. Entrepreneurship Theory and Practice, 35(1): 83-111.

Gibbert, M., Ruigrok, W. \& Wicki, B., 2008. What passes as a rigorous case study?. Strategic Management Journal, 29(13): 1465-1474.

Gilbert, C., Eyring, M. \& Foster, R.N., 2012. Two routes to resilience. Harvard Business Review, 90(12): 6573.

Gittell, J.H., Cameron, K., Lim, S. \& Rivas, V., 2006. Relationships, layoffs, and organizational resilience: Airline industry responses to September 11. The Journal of Applied Behavioral Science, 42(3): 300-329.

Guba, E.G., 1981. Criteria for assessing the trustworthiness of naturalistic inquiries. Educational Technology Research and Development, 29(2): 75 -91.

Hamel, G. \& Valikangas, L., 2003. Why resilience matters. Harvard Business Review, 81(9): 56-57.

Hock-Doepgen, M., Clauss, T., Kraus, S., \& Cheng, C. F. 2020. Knowledge management capabilities and organizational risk-taking for business model innovation in SMEs. Journal of Business Research

Jawadi, F., \& Ftiti, Z. 2019. Oil price collapse and challenges to economic transformation of Saudi Arabia: A time-series analysis. Energy Economics, 80, 12-19.

Jeambey, A.A. 2007. Saudi stock market valuation the case of STC and SABIC. Theses, American University of Beirut, Department of Economics. https://books.google.co.uk/books/about/Saudi_Stock_Market_ Valuation.html?id=8No9MwEACAAJ\&redir_esc=y. 
Jick, T.D., 1979. Mixing qualitative and quantitative methods: Triangulation in action. Administrative Science Quarterly, 24(4): 602-611.

Khanagha, S., Volberda, H. \& Oshri, I., 2014. Business model renewal and ambidexterity: structural alteration and strategy formation process during transition to a $\mathrm{C}$ loud business model. R\&D Management, 44(3): 322-340.

Kiron, D., Kruschwitz, N., Reeves, M. \& Goh, E., 2013. The benefits of sustainability-driven innovation. MIT Sloan Management Review, 54(2): 69-73.

Landau, C., Karna, A. \& Sailer, M., 2016. Business model adaptation for emerging markets: a case study of a German automobile manufacturer in India. R\&D Management, 46(3): 480-503.

Lengnick-Hall, C.A. \& Beck, T.E., 2005. Adaptive fit versus robust transformation: How organizations respond to environmental change. Journal of Management, 31(5): 738-757.

Lerner, J. O. S. H., Leamon, A. \& Dew, S. 2017. The CMA and the Saudi stock market crash of 2006. BELLA Research Group and Saudi Capital Market Authority (CMA). https://cma.org. sa/en/Market/Documents/CMA Crash2006 en.pdf.

Lindgardt, Z., Reeves, M., Stalk, G. \& Deimler, M.S., 2009. Business model innovation. When the Game Gets Tough, Change the Game, The Boston Consulting Group, Boston, MA.

Linnenluecke, M.K., 2017. Resilience in business and management research: A review of influential publications and a research agenda. International Journal of Management Reviews, 19(1): 4-30.

Lipton, M. \& Mazur, R. B. 1975. The Chinese Wall Solution to the Conflict Problems of Securities Firms. New York University Law Review, 50(3): 459-494.

Loon, M. \& Chik, R. 2019. Efficiency-centered, innovation-enabling business models of high tech SMEs: Evidence from Hong Kong. Asia Pacific Journal of Management, 36(1): 87-111.

Mason, K. \& Spring, M. 2011. The sites and practices of business models. Industrial Marketing Management, 40(6): 1032-1041.

Massa, L., Tucci, C.L. \& Afuah, A., 2017. A critical assessment of business model research. Academy of Management Annals, 11(1): 73-104.

Mayring, P. (2014). Qualitative content analysis: theoretical foundation, basic procedures and software solution: GESIS - Leibniz Institute for the Social Sciences.

McNamara, P., Peck, S.I. \& Sasson, A., 2013. Competing business models, value creation and appropriation in English football. Long Range Planning, 46(6): 475-487.

Michel, S. 2014. Capture More Value. Harvard Business Review, 92(8): 80-85.

Morris, M., Schindehutte, M. \& Allen, J., 2005. The entrepreneur's business model: toward a unified perspective. Journal of Business Research, 58(6): 726-735.

Osiyevskyy, O. \& Dewald, J., 2015. Explorative versus exploitative business model change: the cognitive antecedents of firm-level responses to disruptive innovation. Strategic Entrepreneurship Journal, 9(1): 58-78.

Rajala, R., Westerlund, M. \& Möller, K., 2012. Strategic flexibility in open innovation-designing business models for open source software. European Journal of Marketing, 46(10): 1368-1388.

Ramdani, B., Binsaif, A., \& Boukrami, E. 2019. Business model innovation: a review and research agenda. New England Journal of Entrepreneurship, 22 (2): 89-108.

Saebi, T., Lien, L. \& Foss, N.J., 2017. What drives business model adaptation? The impact of opportunities, threats and strategic orientation. Long Range Planning, 50(5): 567-581.

Samargandi, N., Fidrmuc, J. \& Ghosh, S. 2014. Financial development and economic growth in an oil-rich economy: The case of Saudi Arabia. Economic Modelling, 43, 267-278.

Santos, F., Pache, A. C., \& Birkholz, C. 2015. Making hybrids work: Aligning business models and organizational design for social enterprises. California Management Review, 57(3): 36-58.

Schneider, S., \& Spieth, P. 2013. Business model innovation: Towards an integrated future research agenda. International Journal of Innovation Management, 17(1): 1-34.

Sinfield, J.V., Calder, E., McConnell, B. \& Colson, S., 2012. How to identify new business models. MIT Sloan Management Review, 53(2): 85-90.

Sorescu, A., Frambach, R.T., Singh, J., Rangaswamy, A. \& Bridges, C., 2011. Innovations in retail business models. Journal of Retailing, 87(1): 3-16.

Sosna, M., Trevinyo-Rodríguez, R.N. \& Velamuri, S.R., 2010. Business model innovation through trial-anderror learning: The Naturhouse case. Long Range Planning, 43(2-3): 383-407.

Spieth, P., Schneider, S., Clauß, T. \& Eichenberg, D. 2019. Value drivers of social businesses: A business model perspective. Long Range Planning, 52(3): 427-444.

Sutcliffe, K.M. \& Vogus, T.J. 2003. Organizing for resilience. In Cameron, K.S., Dutton, J.E. and Quinn, R.E. (eds), Positive Organizational Scholarship: Foundations of a New Discipline. San Francisco, CA: Berrett-Koehler.

Tallman, S., Luo, Y. \& Buckley, P. J. 2018. Business models in global competition. Global Strategy Journal, 8(4): 517-535. 
Teece, D. J. 2010. Business models, business strategy and innovation. Long Range Planning, 43(2-3): 172-194. Teece, D. J. 2018. Business models and dynamic capabilities. Long Range Planning, 51(1): 40-49.

Tykkyläinen, S., \& Ritala, P. (2020). Business model innovation in social enterprises: An activity system perspective. Journal of Business Research. https://doi.org/10.1016/j.jbusres.2020.01.045.

Velamuri, V. K., Bansemir, B., Neyer, A. K. \& Möslein, K. M. 2013. Product service systems as a driver for business model innovation: lessons learned from the manufacturing industry. International Journal of Innovation Management, 17(1): 1-25.

Velu, C. \& Stiles, P. 2013. Managing decision-making and cannibalization for parallel business models. Long Range Planning, 46(6): 443-458.

Wirtz, B.W., Pistoia, A., Ullrich, S. \& Göttel, V. 2016. Business models: Origin, development and future research perspectives. Long Range Planning, 49(1): 36-54.

Wu, X., Ma, R. \& Shi, Y. 2010. How do latecomer firms capture value from disruptive technologies? A secondary business-model innovation perspective. IEEE Transactions on Engineering Management, 57(1): 51-62.

Yin, R.K. 2014. Case Study Research: Design and methods, 5th Edition. Thousand Oaks: Sage.

Yunus, M., Moingeon, B. \& Lehmann-Ortega, L. 2010. Building social business models: Lessons from the Grameen experience. Long Range Planning, 43(2-3): 308-325.

Publisher's note Springer Nature remains neutral with regard to jurisdictional claims in published maps and institutional affiliations.

Boumediene Ramdani ( $\mathrm{PhD}$, The University of Manchester) is an Assistant Professor of Management at Qatar University. He is a member of the Centre for Entrepreneurship at the College of Business \& Economics. His research interest focuses on how organisations develop and embed innovation capability in response to changing conditions. His research has been published in various journal including: California Management Review, Entrepreneurship and Regional Development, Information \& Management, International Journal of HRM, Journal of Enterprise Information Management, and Journal of Small Business and Enterprise Development among others. Before moving to Qatar, Dr. Ramdani held positions at a number of UK institutions including University of Exeter, UWE-Bristol, and Cranfield. He has acted as a consultant and advisor for a number of private and public institutions including: The World Bank Group, CA Technologies, and Datamonitor.com among others.

Ahmed Binsaif (PhD, University of Exeter) is currently a consultant in a governmental unit in Saudi Arabia. He obtained MSc accounting and financial management from UWE business school. Additionally, He is a certified management accountant by the Institute of Management Accountants (USA). His research interest in Business model innovation and investment bank industry. He has more than 20 years experience in managerial and financial accounting. Since 2002, he worked for consultancy firms and assets management units in Saudi Arabia.

Elias L Boukrami ( $\mathrm{PhD}$, Manchester Metropolitan University) is an Associate Professor of Banking and Finance at Regent's University London. He is the Head of Programmes' portfolio of Finance, Energy and Trade. His team under his leadership was awarded the 2014 Trustees' Prize for Outstanding Service to Regents University London. In 2018, he won a double award prize of Excellence in Teaching and Learning and the Prize of Leadership and Management. He is the Associate Director of the Regent's Transnational Centre for Business and Management. He has over 30 publications including internal peer reviewed journals, books, books chapter and conference papers. He also examined and supervised over $12 \mathrm{PhD}$ thesis and is the associate editor of two peer reviewed academic journals.

Cherif Guermat (PhD, University of Exeter) is a Professor of Empirical Finance in the Department of Accounting, Economics and Finance at the Faculty of Business and Law, the University of the West of England. He is Visiting Professor in Finance at the Universities of Blida and Ouargla, Algeria. He is also an associate member of Exeter Centre for Finance and Investment, University of Exeter. Professor Guermat has published extensively in finance, economics, management and education. He has over 50 publications, including reviewed articles in international journals such as the Journal of World Business and Journal of Banking and Finance, working papers and book chapters. He has supervised and examined over $30 \mathrm{PhD}$ students. 